\title{
Pengaruh Kepuasan Kerja Terhadap Kinerja Pegawai Kejaksaan Negeri Berau
}

\author{
Happy Adianita*, Dados Susilowati, Retno Muslinawati \\ Program Studi Ekonomi Pembangunan, Fakultas Ekonomi, Universitas Bojonegoro, Jawa Timur, Indonesia \\ Email: 1," nitaadiahappy@gmail.com, ${ }^{2}$ dadossusilowati99@gmail.com, ${ }^{3}$ retnomuslinawati@ unigoro.ac.id \\ Penulis Email Korespondensi: nitaadiahappy@gmail.com \\ Submitted: 20/11/2021; Accepted: 28/11/2021; Published: 30/11/2021
}

\begin{abstract}
Abstrak-Penelitian ini bertujuan untuk mengetahui pengaruh kepuasan kerja terhadap kinerja pegawai Kejaksaan Negeri Berau. Dimana variabel bebas kepuasan kerja terdiri dari pekerjaan itu sendiri dan rekan kerja. Desain penelitian yang digunakan adalah kuantitatif deskriptif asosiatif. Metode pengumpulan data yang dilakukan adalah menggunakan kuesioner yang disebar. Teknik penentuan sampel menggunakan sampel jenuh dimana semua anggota populasi dijadikan sampel. Sampel yang digunakan dalam penelitian ini berjumlah 30. Hasil penelitian menunjukkan bahwa Variabel pekerjaan itu sendiri dan rekan kerja secara simultan dan parsial mempunyai pengaruh yang positif dan signifikan terhadap kinerja pegawai. Dari hasil kedua variabel bebas yang merupakan variabel yang dominan mempengaruhi kinerja pegawai Kejaksaan Negeri Berau adalah variabel pekerjaan dibuktikan dengan nilai koefisien regresi yang paling besar yaitu 0.472 dibanding koefisien regresi variabel yang lainnya.
\end{abstract}

Kata Kunci: Kepuasan Kerja; Pekerjaan; Rekan Kerja; Kinerja

Abstract-This study aims to determine the effect of job satisfaction on the performance of the Berau District Prosecutor. Where the independent variable of job satisfaction consist of the work it self and co-workers. The research design used is quantitave descriptive associative. The method of data collection is using a distributed questionnaire. The sampling technique uses a saturated sample where all members of the population are sampled. The sampled used in this study amounted of 30 . The results showed that the work variable it self and co-workers simultaneously and partially had a positive and significant influence on employee performance. From the results of the two independent variables which are the dominant variables affecting the performance of the Berau District Prosecutor, the work variable is proven by the largest regression coefficient value, which is 0.472 compared to the regression coefficients of other variables.

Keywords: Job Satisfaction; Work; Co-Workers; Performance

\section{PENDAHULUAN}

Sumber daya manusia merupakan faktor penting penentu kesuksesan organisasi dalam mencapai tujuannya, karena berhasil atau tidaknya organisasi dalam mencapai tujuan sangat tergantung pada kemampuan SDM atau karyawannya dalam menjalankan tugas-tugas yang diberikan. Kemampuan karyawan dalam menjalankan tugastugasnya dapat dilihat melalui kinerjanya, sehingga kinerja karyawan menjadi hal yang sangat penting bagi keberhasilan organisasi (Wirawan, 2013 dalam Wijaya, 2018)

Kinerja karyawan yang baik ditandai dengan adanya kualitas kerja yang baik dalam menyelesaikan setiap pekerjaan yang diberikan oleh pemimpin dengan tepat sesuai waktu yang ditentukan dan dapat mencapai setiap target yang telah ditetapkan oleh organisasi. Kinerja karyawan yang baik akan mengikuti hasil baik pada perkembangan organisasi. Sebaliknya, kinerja karyawan buruk juga akan berdampak negatif pada kesuksesan organisasi.

Bagi organisasi, kepuasan kerja berkaitan dengan usaha untuk meningkatkan efektivitas organisasi dengan cara membuat efektif perilaku karyawan dalam bekerja. Perilaku karyawan yang menopang pencapaian tujuan organisasi adalah merupakan sisi lain yang harus diperhatikan. Ketidakpuasan karyawan dalam bekarja akan mengakibatkan suatu situasi yang tidak menguntungkan baik secara organisasi maupun individu.

Kejaksaan Negeri Berau adalah lembaga negara yang melaksanakan kekuasaan negara, khususnya di bidang penuntutan. Kejaksaan Negeri Berau sebagai salah satu instansi pemerintah, sudah pasti dituntut untuk dapat menyelenggarakan tugas-tugas dan kegiatan secara berdaya guna dan berhasil guna sehingga dapat menunjukkan citra organisasi pemerintah yang berkualitas. Oleh karena itu, kepuasan kerja karyawan merupakan masalah penting yang harus diperhatikan dalam kaitannya dengan kinerja karyawan.

Tujuan dari penelitian ini adalah untuk mengetahui pengaruh kepuasan kerja terhadap kinerja pegawai Kejaksaan Negeri Berau. Dimana variabel bebas kepuasan kerja terdiri dari pekerjaan itu sendiri dan rekan kerja.

\section{METODE PENELITIAN}

Penelitian ini dilakukan pada kantor Kejaksaan Negeri Berau yang terletak di Jalan Pangeran Diponegoro No. 5 Kelurahan Gunung Panjang Kecamatan Tanjung Redeb Kabupaten Berau Provinsi Kalimantan Timur. Untuk mengetahui pengaruh kepuasan kerja terhadap kinerja pegawai, peneliti menggunakan indikator pekerjaan itu sendiri dan rekan kerja sebagai variabel bebas (X) dan kinerja pegawai sebagai variabel terikat (Y). 
Penelitian ini menggunakan desain penelitian kuantitatif deskriptif asosiatif. Penelitian deskriptif untuk mengetahui nilai masing-masing variabel, baik satu variabel atau lebih yang sifatnya independen. Sedangkan penelitian asosiatif untuk mengetahui pengaruh interaksi antara dua variabel atau lebih (Sujarweni, 2015).

Metode pengumpulan data yang dilakukan peneliti adalah menggunakan kuesioner yang disebar. Data primer yaitu data yang bersumber dari penyebaran kuesioner terhadap pegawai Kejaksaan Negeri Berau. Jenis data yang digunakan adalah data primer dan data sekunder. Data primer yaitu data yang bersumber dari penyebaran kuesioner terhadap pegawai Kejaksaan Negeri Berau sedangkan data sekunder yaitu data yang bersumber dari studi kepustakaan dan berbagai lembaga atau instansi terkait ataupun data-data yang diperoleh dari berbagai sumber lainnya yang relevan.

Populasi dalam penelitian ini adalah seluruh pegawai yang berstatus Aparatur Sipil Negara (ASN) Kejaksaan Negeri Berau yang berjumlah 30. Sedangkan teknik penentuan sampel menggunakan sampel jenuh dimana semua anggota populasi dijadikan sampel. Sampel yang digunakan dalam penelitian ini berjumlah 30 .

Untuk menganalisis pengaruh kepuasan kerja terhadap kinerja pegawai Kejaksaan Negeri Berau menggunakan uji asumsi klasik dan analisis regresi berganda. Regresi linier berganda dinyatakan dalam bentuk regresi yang dinyatakan dalam bentuk model persamaan sebagai berikut:

Keterangan :

$$
\mathrm{Y}=\beta_{0}+\beta_{1} \mathrm{X}_{1}+\beta_{2} \mathrm{X}_{2}+\varepsilon
$$

$$
\begin{array}{ll}
\mathrm{Y}=\text { Kinerja pegawai } \\
\mathrm{X}_{1} & =\text { Pekerjaan itu sendiri } \\
\mathrm{X}_{2} & =\text { Rekan kerja } \\
\beta_{1,2} & =\text { Koefisien regresi masing-masing variabel independen } \\
\beta_{0} & =\text { Intersep atau konstanta }
\end{array}
$$

Model penelitian ini adalah untuk mengetahui ada tidaknya pengaruh dari variabel independen (bebas) terhadap variabel dependen (terikat) secara parsial yang dilakukan dengan mengunakan uji t dengan $\alpha=5 \%$ dan secara simultan (uji F). Hasil uji t dilihat dalam tabel coefficients dalam nilai sig. dengan ketentuann jika nilai signifikansi < 5\% maka $\mathrm{H}_{\mathrm{a}}$ diterima dan jika nilai signifikansi > 5\% maka $\mathrm{H}_{\mathrm{a}}$ ditolak. Hasil uji $\mathrm{F}$ dilihat pada tabel coefficients pada nilai sig. dengan ketentuan jika nilai signifikansi $<5 \%$ maka $\mathrm{H}_{\mathrm{a}}$ diterima dan jika nilai signifikansi $>5 \%$ maka $\mathrm{H}_{\mathrm{a}}$ ditolak.

\section{HASIL DAN PEMBAHASAN}

\section{Uji Asumsi Klasik}

1. Multikolinearitas

Uji Multikolinieritas bertujuan untuk menguji apakah pada model regresi ditemukan adanya korelasi antar variabel independen. Model regresi yang baik seharusnya tidak terjadi korelasi di antara variabel independen. Jika VIF yang dihasilkan di antara 1-10 maka tidak terjadi multikolinearitas.

Tabel 1. Nilai VIF

\begin{tabular}{lcc}
\hline \multicolumn{1}{c}{ Variabel } & VIF & Keterangan \\
\hline Pekerjaan & 1.710 & Tidak Terjadi Multikolinearitas \\
Rekan Kerja & 1.710 & Tidak Terjadi Multikolinearitas \\
\hline
\end{tabular}

Sumber: Data Primer yang Diolah, 2021

2. Autokorelasi

Dengan melihat angka Durbin-Watson, dengan ketentuan sebagai berikut:

1. Angka D-W di bawah -2 berarti ada autokorelasi positif

2. Angka D-W -2 sampai +2 berarti tidak ada autokorelasi

3. Angka $\mathrm{D}-\mathrm{W}$ di atas +2 berarti ada autokorelasi negatif

Tabel 2. Uji Autokorelasi

\begin{tabular}{ccc}
\hline Variabel & D-W & Autokorelasi \\
\hline Pekerjaan & 1.659 & Tidak Terjadi \\
Rekan Kerja & & \\
Kinerja & & \\
\hline Sumber: Data Primer yang Diolah, 2021
\end{tabular}

Sumber: Data Primer yang Diolah, 2021

3. Heterokedastisitas

Uji heterokedastisitas bertujuan untuk menguji apakah dalam model regresi terjadi ketidaksamaan varian dari satu pengamatan ke pengamatan yang lain. 


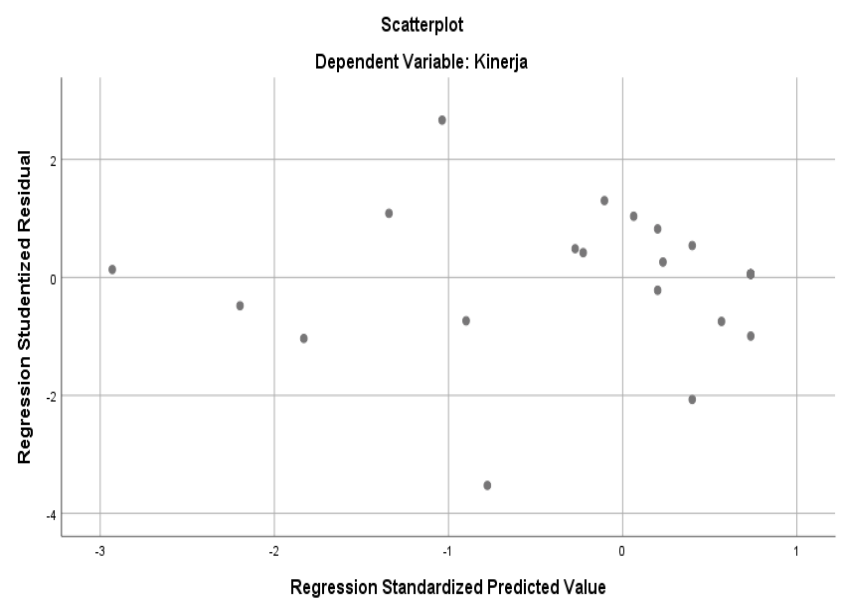

Gambar 1. Uji Heterokedastisitas

Sumber: Data Primer yang Diolah, 2021

Berdasarkan gambar di atas terlihat bahwa tidak ada pola yang jelas serta titik-titik yang menyebar ke atas dan di bawah angka 0 sehingga dapat disimpulkan tidak terjadi heterokedastisitas.

\section{Analisis Regresi Linier Berganda}

Analisis regresi linier berganda dilakukan dengan bantuan SPSS 25.0 dengan tujuan untuk mengetahui seberapa besar pengaruh variabel bebas yang terdiri dari pekerjaan itu sendiri dan rekan kerja terhadap variabel terikat yaitu kinerja pegawai. Model persamaan yang digunakan dalam penelitian ini adalah sebagai berikut:

$$
\mathbf{Y}=\boldsymbol{\beta}_{0}+\boldsymbol{\beta}_{1} \mathbf{X}_{1}+\boldsymbol{\beta}_{2} \mathbf{X}_{2}+\varepsilon
$$

Tabel 3. Analisis Regresi Linier Berganda

\begin{tabular}{|c|c|c|c|c|c|c|}
\hline \multicolumn{7}{|c|}{ Coefficients $^{\mathrm{a}}$} \\
\hline \multirow[b]{2}{*}{ Model } & & \multicolumn{2}{|c|}{ Unstandardized Coefficients } & \multicolumn{3}{|l|}{$\begin{array}{l}\text { Standardized } \\
\text { Coefficients }\end{array}$} \\
\hline & & B & Std. Error & Beta & $\mathrm{t}$ & Sig. \\
\hline 1 & (Constant) & -.347 & 3.266 & & -.106 & .916 \\
\hline & Pekerjaan & .463 & .140 & .472 & 3.316 & .003 \\
\hline & Rekan Kerja & .547 & .178 & .437 & 3.070 & .005 \\
\hline
\end{tabular}

Sumber: Data Primer yang Diolah, 2021

Berdasarkan hasil pengolahan data yang ditunjukkan dalam tabel 3 di atas, maka diperoleh persamaan hasil regresi linier berganda sebagai berikut:

$$
Y=-0.347+0.463 X_{1}+0.547 X_{2}
$$

Berdasarkan persamaan tersebut dapat digambarkan sebagai berikut:

a. Konstanta (a) = -0,347, Konstanta sebesar -0.347 menyatakan bahwa tanpa adanya pekerjaan itu sendiri dan rekan kerja maka besarnya nilai kinerja pegawai sebesar -0.347 .

b. Koefisien $X_{1}\left(b_{1}\right)=\mathbf{0 . 4 6 3}$, ini berarti bahwa variabel pekerjaan itu sendiri $\left(X_{1}\right)$ berpengaruh positif terhadap kinerja pegawai, dengan kata lain jika pekerjaan itu sendiri $\left(\mathrm{X}_{1}\right)$ ditingkatkan sebesar satu-satuan, maka kinerja pegawai akan bertambah sebesar 0.463 .

c. Koefisien $\mathbf{X}_{\mathbf{2}}\left(\mathbf{b}_{2}\right)=\mathbf{0 . 5 4 7}$, ini menunjukkan bahwa variabel rekan kerja $\left(X_{2}\right)$ berpengaruh positif terhadap kinerja pegawai, dengan kata lain jika rekan kerja $\left(\mathrm{X}_{2}\right)$ ditingkatkan sebesar satu-satuan, maka kinerja pegawai akan bertambah sebesar 0.547 .

\section{Uji Hipotesis}

1. Uji Signifikansi Simultan (Uji F). Kriteria pengujiannya adalah:

$\mathrm{H}_{0}: \beta_{1}=\beta_{2}=\beta_{3}=0$, artinya secara serentak tidak terdapat pengaruh yang positif dan signifikan dari variabel bebas terhadap variabel terikat.

$\mathrm{H}_{\mathrm{a}}: \beta_{1}=\beta_{2}=\beta_{3} \neq 0$, artinya secara serentak terdapat pengaruh yang positif dan signifikan dari variabel bebas terhadap variabel terikat.

Tabel 4. Uji Signifikansi Simultan (Uji F)

\begin{tabular}{llcccc}
\hline Model & \multicolumn{4}{c}{ ANOVA $^{\text {a }}$} \\
Sum of Squares & df & Mean Square & F & Sig. \\
\hline
\end{tabular}




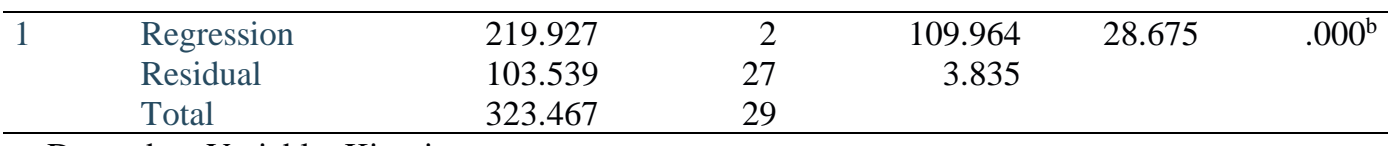

a. Dependent Variable: Kinerja

b. Predictors: (Constant), Rekan Kerja, Pekerjaan

Sumber: Data Primer yang Diolah, 2021

2. Uji Signifikansi Parsial (Uji t). Kriteria pengujiannya adalah:

$\mathrm{H}_{0}: \beta_{1}=\beta_{2}=\beta_{3}=0$, artinya secara parsial tidak terdapat pengaruh yang positif dan signifikan dari variabel independen terhadap variabel dependen.

Ha : $\beta_{1}=\beta_{2}=\beta_{3} \neq 0$, artinya secara parsial terdapat pengaruh yang positif dan signifikan dari variabel independen terhadap variabel dependen.

Berdasarkan kriteria pengujian hipotesis jika nilai signifikansinya $0.000<0.05$, menunjukkan bahwa pengaruh variabel independen (pekerjaan dan rekan kerja) secara serempak adalah signifikan terhadap kinerja pegawai.

Tabel 5. Uji Signifikansi Parsial (Uji t)

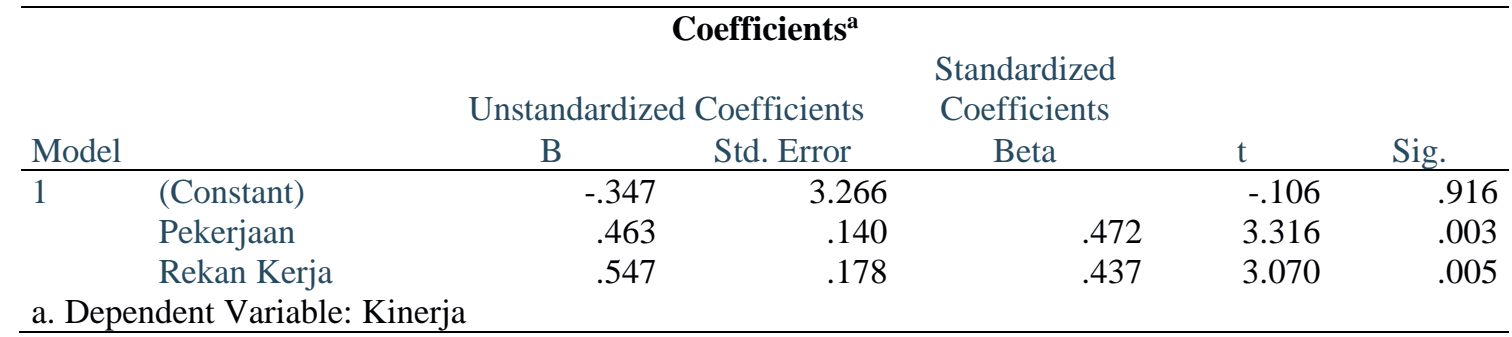

Sumber: Data Primer yang Diolah, 2021

Berdasarkan tabel 5 dapat dilihat bahwa:

1. Variabel Pekerjaan $\left(\mathrm{X}_{1}\right)$

Nilai signifikansinya $(0.003<0.05)$ berarti Ha diterima yaitu secara parsial terdapat pengaruh yang positif dan signifikan terhadap kinerja pegawai Kejaksaan Negeri Berau. Artinya, jika variabel pekerjaann ditingkatkan sebesar satu satuan, maka kinerja pegawai akan meningkat sebesar 0.463

2. Variabel Kepuasan Kerja $\left(\mathrm{X}_{2}\right)$

Nilai signifikansinya $(0.005<0.05)$ berarti Ha diterima yaitu secara parsial terdapat pengaruh yang positif dan signifikan terhadap kinerja pegawai Kejaksaan Negeri Nunukan. Artinya, jika variabel rekan kerja ditingkatkan sebesar satu satuan, maka kinerja pegawai akan meningkat sebesar 0.547.

Dari hasil kedua variabel bebas yang merupakan variabel yang dominan mempengaruhi kinerja pegawai Kejaksaan Negeri Berau adalah variabel pekerjaan dibuktikan dengan nilai koefisien regresi yang paling besar yaitu 0.472 dibanding koefisien regresi variabel yang lainnya.

Pengujian koefisien determinasi $\left(\mathrm{R}^{2}\right)$ digunakan untuk mengukur proporsi atau persentase kemampuan model dalam menerangkan variabel terikat.

Tabel 6. Pengujian Koefisien Determinasi

\begin{tabular}{|c|c|c|c|c|c|}
\hline \multicolumn{6}{|c|}{ Model Summary ${ }^{b}$} \\
\hline Model & $\mathrm{R}$ & R Square & $\begin{array}{l}\text { Adjusted R } \\
\text { Square }\end{array}$ & $\begin{array}{l}\text { Std. Error of the } \\
\text { Estimate }\end{array}$ & Durbin-Watson \\
\hline 1 & $.825^{\mathrm{a}}$ & .680 & .656 & 1.958 & 1.659 \\
\hline $\begin{array}{l}\text { a. Predi } \\
\text { b. Depe }\end{array}$ & $\begin{array}{l}\text { (Constan } \\
\text { Variable }\end{array}$ & $\begin{array}{l}\text { t), Rekan Ker } \\
\text { Kinerja }\end{array}$ & Pekerjaan & & \\
\hline
\end{tabular}

Sumber: Data Primer yang Diolah, 2021

Nilai R Square sebesar 0.680 menunjukkan bahwa kinerja pegawai Kejaksaan Negeri Berau (Y) dipengaruhi oleh variabel pekerjaan itu sendiri $\left(\mathrm{X}_{1}\right)$ dan rekan kerja $\left(\mathrm{X}_{2}\right)$ sebesar $68 \%$, sisanya yaitu $32 \%$ kinerja pegawai Kejaksaan Negeri Berau dipengaruhi variabel lain yang belum diteliti dalam penelitian ini.

\section{KESIMPULAN}

Berdasarkan hasil analisis data dan pembahasan yang telah dilakukan, maka dapat ditarik kesimpulan, variabel pekerjaan itu sendiri dan rekan kerja secara simultan dan parsial mempunyai pengaruh yang positif dan signifikan terhadap kinerja pegawai. Dari hasil kedua variabel bebas yang merupakan variabel yang dominan mempengaruhi kinerja pegawai Kejaksaan Negeri Berau adalah variabel pekerjaan dibuktikan dengan nilai koefisien regresi yang 
paling besar yaitu 0.472 dibanding koefisien regresi variabel yang lainnya. Kepuasan kerja mempengaruhi kinerja pegawai. Dengan adanya kepuasan kerja yang diperoleh, diharapkan kinerja pegawai yang tinggi dapat dicapai. Tanpa adanya kepuasan kerja, pegawai akan bekerja tidak seperti apa yang diharapkan oleh organisasi, maka akibatnya kinerja pegawai menjadi rendah, sehingga tujuan organisasi secara maksimal tidak akan tercapai. Adapun saran yang dapat di berikan untuk meningkatkan kepuasan kerja agar mencapai kinerja yang optimal perlu dilakukan cara agar semua hak-hak pegawai diberikan dengan baik dan tepat waktu, juga selalu menjaga hubungan yang baik dengan rekan kerja, atasan maupun bawahan ataupun dengan mengadakan pertemuan non formal agar hubungan selalu terjaga dengan baik. Untuk penelitian selanjutnya, hendaknya ditambahkan variabel independen yang lain yang merupakan faktor yang mempengaruhi kinerja pegawai yang dapat menunjang hasil penelitian ini.

\section{REFERENCES}

Frizkha, Hariana. 2021. Pengaruh Kepuasan Kerja dan Stres Kerja Terhadap Kinerja Karyawan PT. Mekar Karya Mas. Jurnal Humaniora. Volume 5 No. 1 (170-183), http://jurnal.abulyatama.ac.id/humaniora

Hasibuan, S.P. Malayu. 2013. Manajemen Sumber Daya Manusia Edisi Revisi. Jakarta: PT. Bumi Aksara

Pambudy, A. P., \& Syairozi, M. I. (2019). Analisis Peran Belanja Modal dan Investasi Swasta Terhadap Pertumbuhan Ekonomi Serta Dampaknya Pada Kesejahteraan Masyarakat. Jurnal Ekonomi dan Bisnis, 20(1), 26-39.

Priyatno Duwi. 2016. Belajar Alat Analisis Data dan Cara Pengolahannya Dengan SPSS. Yogyakarta: Gava Media

Ririn Nur Indah Sari, Hady Siti Hadijah. 2016. Peningkatan Kinerja Pegawai Melalui Kepuasan Kerja dan Disiplin Kerja. Jurnal
Pendidikan
Manajemen
Perkantoran.
Volume
1
No.
1
(204-214),

Riski Damayanti, Agustina Hanafi, Afriyadi Cahyadi. 2018. Pengaruh Kepuasan Kerja Terhadap Kinerja Karyawan (Studi Kasus Karyawan Non Medis RS. Islam Siti Khadijah Palembang). JEMBATAN (Jurnal Ilmiah Manajemen Bisnis dan Terapan). Volume XV No. 2 (75-86), http://ejournal.unsri.ac.id/index.php./jembatan

Sujarweni, V. Wiratna. 2015. Metodologi Penelitian Bisnis dan Ekonomi. Yogyakarta: Pustaka Baru Press

Sunyoto, Danang. 2015. Penelitian Sumber Daya Manusia. Jakarta: PT.Buku Seru

Sutrisno, Edy. 2013. Manajemen Sumber Daya Manusia. Jakarta: Kencana Prenada Media Group

Susanti, I., Syairozi, M. I., \& Lukman, H. Y. W. (2021). Analisis Sistem Manajemen Dalam Pengelolaan Bumdes Di Desa Bluluk. Jurnal Sains Sosio Humaniora, 5(2), 701-710.

Syairozi, M. I. (2011). Analisis peranan sektor pertanian terhadap produk domestik regional bruto (PDRB) di kabupaten Malang (periode 2000-2008) (Doctoral dissertation, Universitas Negeri Malang).

Wijaya, Iwan Kurnia. 2018. Pengaruh Kepuasan Kerja Terhadap Kinerja Karyawan CV. Bukit Sanomas. AGORA. Volume 6 No. 2 